\title{
Assessment of honey production system, constraints and opportunities in Ethiopia
}

\begin{abstract}
Summary
This paper is mainly focused on the assessment of honey production system, constraints and opportunities in Ethiopia. Ethiopia is one of the countries in the continent which possess huge honey production potential. Beekeeping in Ethiopia is a long-standing agricultural practice. It has been exercised as a sideline activity by many of the rural farming communities for its honey and beeswax production that contributes to income generation. Beekeeping is a major integral component in agricultural economy of developing countries. The most important and available insect in the world today is the honeybee. There are several species of honeybees existing, but Apis mellifera is country famous. It is a wonderful and popular bee type for There are four different types of beekeeping practices in Ethiopia namely, traditional forest, traditional backyard, transitional and improved or modern beekeeping. Beekeeping is a very long-standing practice in the farming communities of the Tigray region and it plays a significant role as source of additional cash income and nutrition for many subsistence farmers. The major constraints that affect beekeeping sub-sector in Ethiopia are: lack of beekeeping knowledge, shortage of skills man power, shortage of bee equipments, pests and predators, pesticide threat, poor infrastructure development, shortage of bee forage and lack of research extension. Therefore efforts should also be geared to reduce the main constraints that hindered beekeeping development.
\end{abstract}

Keywords: assessment, beekeeping, constraint, opportunities, Ethiopia
Volume 6 Issue I - 2018

\author{
Haftey Sahle, Gashaw Enbiyale, Ayalew \\ Negash, Tsehaye Neges \\ College of Veterinary Medicine and science, University of \\ Gondar, Ethiopia
}

Correspondence: Gashaw Enbiyale, Field Practitioner at University of Gondar Veterinary hospital, College of Veterinary Medicine and science, University of Gondar, P.O. Box. 196, Gondar, Ethiopia, Email enbiyalegashaw@gmail.com

Received: September II, 2017 | Published: February 07, 2018

\section{Introduction}

Africa is blessed with numerous types of wild honeybees. Ethiopia is one of the countries in the continent which possess huge honey production potential. Owing to its varied ecological and climatic conditions, Ethiopia is the home of diverse flora and fauna in Africa. In Ethiopia, ancient tradition for beekeeping is stretched back into the millennia of the country's early history which created a difficult to establish a time reference when beekeeping was started. However, some report confirmed that it was started a date 5000years back and the Hieroglyphs of ancient Egypt refers to Abyssinia used as the source of honey and beeswax. Thus, Abyssinia has been known for its bee wax export for centuries during when other items were not exportable. ${ }^{2}$ Since, it had ideal climatic conditions and diversified floral resources which allow the country to sustain around 10million honeybee colonies ( 7 million were kept in local beehives by farmers and the remaining exist in the forests as wild colonies) and makes the country to have the highest bee density and the leading producer of honey and beeswax in Africa.,

Therefore, Ethiopian annual honey production was estimated about 43,373 metric tons which is shared with about $23.5 \%$ and $2.35 \%$ of African and world's honey production, respectively. This makes the country rank $1^{\text {st }}$ in Africa and $10^{\text {th }}$ in the world. ${ }^{5}$ Because, of more than 7000 species of flowering plants which most of them are honeybee plants $^{6}$ and variety of landscape differences has given the country better honey production within a consequent seasons. ${ }^{7}$ In addition, long tradition of beekeeping is made Ethiopia having the highest bee density and being the leading honey producer as well the largest beeswax exporting countries in Africa. Nevertheless, productivity has always been low, leading to low utilization of hive products domestically, and relatively low export earnings. Thus, the beekeepers in particular and the country in general are not benefiting from the sub sector. ${ }^{4}$ Investigation indicated that the number of the honeybee colonies in the country has been declining and consequently the honey and beeswax production as well as export earnings fell down. ${ }^{8}$ This is attributed to drought, ever- expanding population pressure and associated vegetation changes and indiscriminate applications of chemicals. Moreover, the products obtained from this sub sector are still low, poorly managed and unattractive in appearance as compared to the potential of the country. Because of this, its place in the local market is being taken by imported honey. The type of hives used the methods of removing and storage of honey play a vital role in the quality of honey. ${ }^{9,10}$

The major constraints that affect beekeeping sub-sector in Ethiopia are: lack of beekeeping knowledge, shortage of skills man power, shortage of bee equipments, pests and predators, pesticide threat, poor infrastructure development, shortage of bee forage and lack of research extension Low and productivity and quality of bee products are the major economic impediments for beekeepers. ${ }^{11}$

The general and specific objectives of this seminar are:-

i. To assessment of honey production systems

ii. To characterize honey bee production

iii. To identify the associated constraints of honey bee production

iv. To identify opportunities of beekeeping

\section{Literature review}

\section{History of beekeeping in Ethiopia}

Beekeeping in Ethiopia is a long-standing agricultural practice. It 
has been exercised as a sideline activity by many of the rural farming communities for its honey and beeswax production that contributes to income generation. Even though, it is one of the important and oldest farming activities in the country, there are no civil able records, which confirm when and where beekeeping was first started. However, hieroglyphs of ancient Egypt refers to Abyssinia (ancient home Ethiopia), as source of honey and bees wax and Abyssinia has been for its bees wax exported to Egypt for country when other items were not exported. ${ }^{12}$ It is assumed that keeping of bees in baskets may have started about 5000years ago and no countries in the world may have to ancient beekeeping as Ethiopia. ${ }^{2-13}$ Moreover, the oldest basket hive in the international bee museum is from Ethiopia. Currently there are an estimated tenmillion bee colonies are found in the country, out of which about 7.5 million are confined in hives and the remaining exist in the forest and wild. In the western part of Ethiopia, there are beekeeping practices who own up to one thousand bee colonies. They do not count the number of hives but only the number of reason which the hives are hanging.

\section{Origin and evolution of bees and beekeeping}

Bees likely evolved from wasp like ancestors, contemporaneously with the angiosperm plants towards the end of cretaceous period, 60 to 100 million years ago. ${ }^{14}$ According to Dietz \& Rinderer ${ }^{15}$ the present bee fauna probably originated more than 70million years ago. Currently, eleven families of bees are generally recognized, only some of which are identified by derived traits setting them apart from other bee families. There are about 1000 geniuses (and sub genus), combined with sub genera, approximately 600 generic groups and an estimated 20,000 living species of bees residing in the world's museums. ${ }^{16}$ Bees (Apoidea) are a super family of about 20,000 species, in the order Hymenoptera. The majority of bee species are 'solitary' while the minorities are social (bumble bees and stingless bees), and only a few species of social bees, are kept in hives by beekeepers. There are three families of social bees, which produce honey. These are: the Bombidae, Meliponidae and Apidae .The Bombidae are found mainly in temperate climates. Their nests are very small, often in the ground and are of no commercial importance except as pollinators of certain plants. ${ }^{17}$ The Meliponidae, or stingless bees, occur throughout the tropical regions of the world. Their nesting places may be holes in the ground, in hollow trees or small cavities in walls and on the underside of branches. The family Apidae, to which the honeybee belongs, is indigenous only to Europe, Africa and Asia. ${ }^{9-18}$ A honey bee found in East Africa was reported from the upper Pleistocene period, 100,000years ago. ${ }^{15}$ This bee could not be differentiated from the contemporary African honeybee species..$^{15}$ Beekeeping, which is today practiced over a greater area of the earth's surface than perhaps any other single branch of agriculture, passed through different stages of development: honey hunting, traditional (forest and backyard) and improved (movable-frame and movable top-bar) methods of beekeeping. It is likely that man hunted for wild nests of bees and looked for their honey during the whole of his existence. Early man probably took honey from bees' nests wherever he found them, and the collection of honey from wild nests continued except in some regions where it has been entirely superseded by beekeeping. ${ }^{9}$

\section{Beekeeping and the environment of Ethiopia}

Beekeeping is a major integral component in agricultural economy of developing countries. Current interest in quality of environment is influencing the people to look more deeply at the factors upon which food production, health and aesthetic aspects of the environmental depend. ${ }^{14}$ Whereas, the geographical distribution of honeybees and morphometric analyses of Ethiopian honeybees are categorized at Apis Mellifera Monticola from the Ethiopian plateaus and later, ${ }^{19}$ the presence of A.m. scutellataand A.m. Jemenitica ${ }^{20}$ and Ayalew ${ }^{21}$ suggested that the existence of five honeybee races like Apis Mellifera Jemenitica (in eastern lowlands), A.m. Monticola (in the southern mountains), A.m. Litorea (in the extreme western low lands), A.m. Adansonii (in the southern mid-altitude areas) and A.m. Abyssinica (central plateau and southwestern parts of tropical forest). Radloff \& Hepburn $^{22}$ recorded A.m. Jemenitica, A.m. Bandasiiand A.m. Sudanensis from Ethiopia. However, these findings are inconsistent except for A.mmonticola and A.m. Jemenitica and none of the results indicated the distribution, behavior and biology of these honeybees for the whole of Ethiopia. ${ }^{23}$ More recently, the northern regions of the country (located between $90 \mathrm{~N}$ and 14.530 latitudes north and 340 and 440 longitudes east), most of which were not covered by Ayalew were studied by $\mathrm{Nuru}^{4}$ and revealed the existence of four discrete geographical races. These are A.m. Jemenitica from eastern, northwestern, and northern arid and semi-arid lowlands, A.m. Scutellata form the western humid midlands, A.m. Bandasii from sub-moist central highlands and A.m. Monticola from northern mountainous parts of the country. Moreover, the southern Ethiopia region (located between $4049^{\prime} 54.3$ " North to 90 7' $98^{\prime \prime}$ "North latitude and 340 16' 07' East to 420 57' 57' East longitude) were studied by $\mathrm{Amssalu}^{23}$ and four distinct morph clusters were reported in the study area: the smallest and yellow honeybee, A.m. Woyi-gamballain the western and southern lowlands; the small and yellowiest honeybees, A.m. Jemeniticain the eastern escarpment; relatively large and dark honeybees, A.m. Bandasiiin the central and eastern high lands; and dark honeybees, A m. Scutellata in the wet tropical forests. The results of the northern and southern regions were well fitted to each other and multivariate morphometric analysis of the merged data (northern and southern) revealed the existence of five statistically separable morph clusters occupying ecologically different areas: Apis mellifera Jemenitica in the northwest and eastern arid and semi-arid lowlands; A.m. Scutellata in the west, south and southwest humid midlands; A.m. Bandasii in the central moist highlands; A.m. Monticola from the northern mountainous highlands; and A.m. woyi-gambella in south western semi-arid to sub-humid lowland parts of the country. ${ }^{23}$

\section{Honeybee species in Ethiopia}

The most important and available insect in the world today is the honeybee. There are several species of honeybees existing, but Apis mellifera is country famous. It is a wonderful and popular bee type for its honey and beeswax production besides the major value obtained because of plant pollination. ${ }^{3}$ Different Researchers have studied the identification of honeybee races of Ethiopia. Apis mellifera monticola was the first honeybee race reported to exist in the Ethiopian plateau as noted by Smith. ${ }^{4-19}$ Ayalew $^{21}$ identified the existence of five honeybee races in Ethiopia. These are: Apis mellifera adansanii exists in south and western part of the country, Apis mellifera jemenitica founds in the low land areas of eastern Ethiopia, Apis mellifera monticola exists in Southeast Mountain of Bale-Dinsho, Apis mellifera litorea exists in southwest low lands, Apis mellifera abyssinica exists in highland area of central, west and southern parts of the country.

\section{Bee keeping production system in Ethiopia}

Apiculture is a promising off-farm enterprise, which directly and indirectly contributes to smallholder's income in particular and nation's economy in general. It has significant role in generating and 
diversifying the income of subsistence Ethiopian smallholder farmers mainly the small land holders and landless. ${ }^{2}$ Ethiopia is known for its tremendous variation of agro-climatic conditions and biodiversity which favored the existence of diversified honeybee flora and huge number of honeybee colonies. ${ }^{24}$ Currently Ethiopia is listed as a third country to export honey by European commission. To export to European Union a number of requirements must be met the primary and the secondary requirements. The primary requirements listed were: viable offer to the market, listed in the EU inventory of third countries eligible to export honey to EU and clean honey. The secondary requirements $\mathrm{s}$ comprised of: Business relation with the buyer, a traceability system for quality control and Hazard analysis and critical control points concept. ${ }^{25}$ According to Holeta Bee Research Center ${ }^{26}$ there are four different types of beekeeping practices in Ethiopia namely, traditional forest, traditional backyard, transitional and improved or modern beekeeping.

Traditional forest Beekeeping: In Ethiopia, traditional beekeeping is the oldest and the richest practice, which has been carried out by the people for thousands ofyears. Severalmillion bee colonies are managed with the same old traditional beekeeping methods in almost all parts of the country. ${ }^{13-27}$ Traditional beekeeping is of two types: forest beekeeping and backyard beekeeping. In some places, especially in the western and southern parts of the country, forest beekeeping by hanging a number of traditional hives on trees is widely practiced. In other most parts of the country backyard beekeeping with relatively better management is common. ${ }^{4}$ Traditional beekeeping is mostly practiced with different types of traditional hives. The most universal type of traditional hives, known to have been in use is simple cylindrical type. Beekeeping started with traditional or fixed comb hives, so called because the combs are attached to the top and sides of the hive itself and the beekeeper cannot easily remove and replace them.

Traditional back yard beekeeping: It is undertaken in safeguarded area for honeybees mostly at homestead. The advantages of such practices are: construction is very simple, it does not require improved beekeeping equipment; it does not also require skilled manpower; whereas its disadvantages are inconvenience to undertake internal inspection and feeding, in some places the size is too small and causes swarming, it has no possibilities of supering, there is no partition to differentiate brood chamber and honey chamber. ${ }^{28}$

Transitional system of beekeeping: It is a type of beekeeping intermediate between traditional and modern beekeeping methods. Generally, top-bar hive is a single story long box with slopping sidewalls inward toward the bottom (forming an angle of $115 \mathrm{o}$ with the floor) and covered with bars of fixed width, $32 \mathrm{~mm}$ for east African honeybees, ${ }^{29,30}$ Adjare $^{1}$ and IBRA $^{31}$ suggested that for technical and economic reasons, most African countries are not yet in the position to use movable-frame hives, and for them top-bar hive represents a satisfactory compromise.

Modern (frame-hives) (improved) system of beekeeping: Modern beekeeping methods aim to obtain the maximum honey crop, season after season, without harming bees. ${ }^{30}$ Modern movable- frame hive consists of precisely made rectangular box hives (hive bodies) superimposed one above the other in a tier. The number of boxes is varied seasonally according to the population size of bees. Practical movable- frame hive was invented in 1851 by Lorenzo Lorraine Lang troth in U.S.A. ${ }^{32,33}$ Later on different countries developed their own movable frame hives (for instance Zander, Dadant) and Langstroth was the prototype of movable frame hives used today. In many countries Lang troth hive boxes have proved to be convenient for handling and management.

\section{Bee keeping production system in Tigray}

Beekeeping is a very long-standing practice in the farming communities of the Tigray region and it plays a significant role as source of additional cash income and nutrition for many subsistence farmers. It is an integral part of the smallholder farming system. In Tanqua Abergelle, Kola Tembien and Werie lekes districts, Central zone Tigray, Northern Ethiopia, apiculture is a good source of income for smallholder farmers, as both honey and bee colonies are in high demand. ${ }^{34}$ Beekeeping production practice in Tigray is similar as elsewhere in Ethiopia. It is an ancient farming activity which is practiced by the beekeepers as sideline activities with other farm practices. Beekeeping using bark and basket hives have long been part of the subsistence economy of people in the area. Honey hunting is practiced by many people on an opportunistic base in the forest dominated localities in the zone On the other hand, beekeeping can be described as a way of life initially practiced by small group of people and the skill passed on from generation to generation within families. The traditional beekeepers work within a framework set by the subsistence need of the household. ${ }^{35}$

\section{Economic importance of beekeeping in Ethiopia}

Beekeeping has been part of the farming system in Ethiopia since time immemorial. It has been a tradition since long before other farming systems. Beekeeping is a very long-standing and deep-rooted practice in the rural communities of the country and around one million farmers are estimated to keep bees. ${ }^{27}$ Beekeeping has been and still plays a significant role in the national economy of the country as well as for the subsistence smallholder farmers. The socio-economic impact of beekeeping and the main hive products and importance of beekeeping are summarized as follows:

Honey production: Honey, the natural product of honeybee is an excellent energy source because it contains simple sugars that are ready for assimilation immediately on reaching the intestine. Honey contains more than 180 elements and it has several uses. ${ }^{22}$ There is a strong, local demand for honey, due to its use for the production of traditional beverage 'Tej' (honey mead). In Ethiopia, much honey has traditionally been fermented to make 'Tej' and according to Edessa ${ }^{10}$ 85 percent of the total honey estimated to be brought for market is used for 'Tej' production and 15 percent of the total honey produced is consumed at home. Moreover, from the total honey produced in the country beekeepers are estimated to earn about 360-480million Birr Per year. ${ }^{4}$ The current annual honey production of Ethiopia is estimated to be about 43,373 tones. ${ }^{5}$ This makes the country the leading honey producer in Africa and one of the ten largest honey-producing countries in the world.

Beeswax production: In several regions of the country, beeswax collection is not significant and the beeswax produced by bees, which could be harvested by beekeepers, is wasted. The wax is mostly left or thrown away because beekeepers do not bother to collect it since it is of little practical value for beekeepers ${ }^{13}$ and the people do not know the local beeswax is generating attractive money. Nevertheless, the annual beeswax production of the country is estimated at about 3,658tones. ${ }^{5}$ This makes Ethiopia the fourth largest beeswax producing country in the world after China, Mexico and Turkey. Beeswax supports the national Economy through foreign exchange earnings. Presently, beeswax is one of the major exportable agricultural products. Ethiopia is the third largest beeswax exporter in Africa and the annual average value of beeswax is estimated at about 125 million Birr. ${ }^{4}$ Like honey, beeswax is also a multipurpose natural bee product, which is used in the manufacture of more than 300 commodities. Honey 
and beeswax also play a big role in the cultural and religious life of the people of the country.

Crop pollination: Bees are essential parts of the agricultural system. Although the value of honeybees in crop pollination is under estimated, it has a significant role in increasing national food production and regeneration of plant species. Honeybees are the prime pollinating agents in the world. Their service in pollination is estimated to be worth over 15times the value of all hive products together, although it is much more difficult to quantify their benefit. ${ }^{36}$ Hackett $^{28}$ estimated the value of honeybee pollination to U.S. agriculture to be 14billion U.S \$ annually. Honeybee is also believed to play a significant role in the economy of Ethiopia through pollination services. Pollination is one of the most important factors that affect seed production in agricultural crops. In Ethiopia, an experiment was conducted to determine the effect of pollination on Niger (Guizotia abyssinica) and the result showed that honeybees increased the seed yield of Niger by about $43 \%{ }^{37}$ and Onion (Allume Cepa) by two fold. ${ }^{38}$

Source of immediate cash income: Beekeeping is believed to play a significant role and one of the possible options to the smallholder farmers in order to sustain their livelihood. In Tigray, the price of one established bee colony in a traditional hive ranged from 300-800 Birr, ${ }^{4}$ which was worth enough to buy about 3-5 sheep and goats or a heifer. On the other hand, some beekeepers in Amhara region that are involved in beekeeping technology packages, were reported to earn up to 3000 birr annually from sale of honey, ${ }^{39}$ making up for the large portion of their annual income. The same source indicated that high potentiality of beekeeping as a source and means of diversification of income for the rural communities. In Jimma Zone of Oromia Regional State, beekeepers are reported to earn up to 40,000 birr/annum. In some tribes the entire livelihood of a community solely depends on honey selling.

\section{Major constraints of beekeeping in Ethiopia}

Ethiopia has enormous untapped potential for promoting beekeeping; both for local use and for export purpose. However, like any other livestock sector, this sub sector has been ceased by complicated constraints. The prevailing production constraints in the beekeeping sub sector of the country would vary depending on the agro ecology of the areas where the activities is carried out. ${ }^{10}$ According to HBRC,,$^{22}$ Ayalew $^{3}$ and Edessa, ${ }^{10}$ the major constraints in the beekeeping sub sector are the following:

High cost of modern bee hives: Some of the bee equipments such as modern bee hives, wax printers and honey extractors are very expensive and thus farmers could not affordable to buy and use these equipments. Currently, the cost of one modern bee hive ranges from 9001000 ETB. The cost of honey extractor is ranges 4,000-5,000 ETB and the cost of wax printer is ranges from 5,000-6,000 ETB. As a result of these, there is a shortage of appropriate technologies for production, collection, processing, packing and storage in the area. Improved bee equipments to the district farmers are beyond their buying capacity and even is not easily available for those beekeepers who are afford to buy it. The participants also indicated that there is no microfinance institutions that financing or provide credit services for those farmers who want to invest in modern honey production in the district. Most of the district farmers were resource poor and thus they are unable to buy and use modern bee technologies to improve honey yield.

Pests and predators: Ethiopia, as one of the sub-tropical countries, the land is not only favorable to bees, but also for different kinds of honey bee pests and predators that are interacting with the life of honey bees. ${ }^{40}$ Pests and predators cause a serious devastating damage on honey bee colonies with in short period of time and even over night. The major bee pests and predators in the district were: wax moth, spider, ants, bee-eater birds, honey badger and beetles are the most serious problems to beekeeping development. This result agrees with the report of ${ }^{41}$ ants, honey badger, bee-eater birds, wax moth, spider, and beetles were the most harmful pests and predators in order to decreasing importance of beekeeping in Amhara region.

Shortage of flowering plants: This problem is directly related to deforestation of forest coverage from time to time for timber making, construction, fire wood and expansion of agricultural lands. These are cause shortage of bee forage especially during the dry season. Most beekeepers of the district have been migrating their bee colonies from their area to other area during the dry season for searching bee forage. This will increase the expense of farmers in the form of wage and cause colony loss through pests and predators. The elimination of good nectar and pollen producing tree species in many areas make it difficult to maintain bee colonies without feeding. ${ }^{41}$ Due to deforestation and poising of agro-chemicals, the honey bee population is in state of continues declining. As a result, it has become a serious challenge to get honey bee colonies to start and expand beekeeping. ${ }^{4}$ Beekeeping sector is dependent on healthy flora and a healthy environment. Recentyears have seen environmental changes in Ethiopia in terms of erratic rain fall patterns and deforestation. If these problems worsen, the beekeeping sector could be affected. ${ }^{42}$

Lack of government intervention: Majority of the beekeepers lack the knowledge of appropriate methods of beekeeping. In the country there is no concerned college or university which can provide diploma or certificate level course in beekeeping. Holeta Bee Research Center is the only institute that provides basic trainings to farmers, extension workers and experts. However, this doesn't meet the ever increasing demand of trained manpower in the region.

Lack of skilled man power: Beekeeping is one of the disciplines which suffered and is being suffering from lack of skilled man power, training majority beekeepers of appropriate methods of beekeeping. ${ }^{10}$

\section{Opportunities of honey bee production}

The direct contribution of beekeeping includes the value of the outputs produced such as honey, bee wax, queen and bee colonies, and other products such as pollen, royal jelly, bee venom, and propolis in cosmetics and medicine. ${ }^{8}$ Plentiful forage availability coupled with favorable and diversified agro-climatic conditions of Ethiopia create environmental conditions conducive for the growth of over 7000 species of flowering plants which has supported the existence of large number of local bee colonies in Ethiopia. It is estimated that over twomillion bee-colonies in the countries exists in the forest and crevices. The density of hives occupied by the honeybees on the land may be the highest, at the present moment, of any country in the African continent. ${ }^{43}$ In Ethiopia, beekeeping is an integral part of the life style of the farming communities, and except for a few extreme areas, it is a common practice in every place where humankind has settled. In addition, Ethiopia has probably the longest tradition of all the African counties in beeswax and honey marketing. ${ }^{44}$

\section{Conclusion and recommendations}

Ethiopia is one of the countries in the continent which possess huge honey production potential. Beekeeping is a major integral 
component in agricultural economy of developing countries. Apiculture is a promising off-farm enterprise, which directly and indirectly contributes to smallholder's income in particular and nation's economy in general. ${ }^{45-53}$ It has significant role in generating and diversifying the income of subsistence Ethiopian smallholder farmers mainly the small land holders and landless. In Ethiopia, traditional forest, traditional back yard, transitional and modern systems of types of honey production are common. Beekeeping has been and still plays a significant role in the national economy of the country as well as for the subsistence smallholder farmers. The direct contribution of beekeeping includes the value of the outputs produced such as honey, bee wax, queen and bee colonies, and other products such as pollen, royal jelly, bee venom, and propolis in cosmetics and medicine. The major constraints that affect beekeeping sub-sector in Ethiopia are: lack of beekeeping knowledge, shortage of skills man power, shortage of bee equipments, pests and predators, pesticide threat, poor infrastructure development, shortage of bee forage and lack of research extension. ${ }^{54-59}$

Based on the above conclusions the following recommendations are forwarded:

a) Increasing the productivity, production and quality of honey by improving the management of the traditional hives and introducing improved beehives, increasing the productiveness of bee colonies by improving bee forage and providing feed and water and introducing bee plants is very important.

b) Besides, establishing honey and beeswax collection centers or cooperatives and Equipping them with the necessary facilities should be done.

c) Efforts should also be geared to alleviate the main constraints that hindered beekeeping development in the district.

d) Promote beekeeping sub-sector strategy that would be applicable to different Production systems.

e) Indigenous knowledge of farmers in beekeeping should be scientifically examined.

\section{Acknowledgements}

None.

\section{Conflict of interest}

Author declares that there is no conflict of interest.

\section{References}

1. Adjare SO. Beekeeping in Africa. FAO Agricultural Services Bulletin 68/6. Food and Agriculture Organization of the United Nations. Italy; 1990.

2. Gezahegne T. Beekeeping (In Amaharic). Ethiopia: Mega Printer Enterprise; 2001.

3. Ayalew K. Promotion of beekeeping in rural sector of Ethiopia: Proceedings of the third National Annual Conference of Ethiopian Beekeepers Association (EBA). Ethiopia, 2001:52-58.

4. Nuru AM. Geographical races of the Honeybees (Apis mellifera) of the Northern Regions of Ethiopia. Rhodes University, South Africa; 2002. p. 1-288.

5. Central Statistical Authority. Agricultural Sample Survey: Report on Livestock, Poultry and Beehives Population. Ethiopia: Statistical Bulletin; 1995.
6. Girma D. Non-Wood Forest Products in Ethiopia: EC-FAO Partnership Programme (1998-2000). Ethiopia; 1998.

7. Gebreyesus M. Practical aspects of bee management in Ethiopia: Proceedings of the first international conference on apiculture in tropical climates. UK; 1976. p. 69-78.

8. Gezahegne T. Marketing of honey and beeswax in Ethiopia: past, present and perspective features: Proceedings of the third National Annual Conference of the Ethiopian Beekeepers Association (EBA). Ethiopia, 2001:78-88.

9. Crane E. Bees and beekeeping: Science, practice and world resource. USA: Cornell University Press; 1970. p. 1-640.

10. Edessa N. Survey of honey production system in West Shewa Zone: Proceedings of the 4th Ethiopian Beekeepers Association (EBA). Ethiopia; 2005.

11. Kerealem. Bee keeping in the Amhara region rd. Ethiopian beekeeping association (EBA). 2009:52-58.

12. Gezahegne T. Zooming in on Ethiopia. The journal for sustainable beekeeping: Beekeeping and Development. 1996;40:11.

13. Fichtl R, Admasu A. Honeybee Flora of Ethiopia: Some 500 Common Herbs, Shrubs and Trees. Germany: Margraf Publishers; 1994. p. 1-510.

14. Martin EC. The use of bees for crop pollination. In: The Hive and the Honey Bee. USA: Dadant \& Sons Publishing; 1976. p. 579-614.

15. Dietz A, Rinderer TE. Bee Genetics and Breeding. USA: Northern Bee Books; 1986. p. 1-444.

16. Roubik DW. Ecology and Natural History of Tropical Bees. USA: Cambridge University Press; 1989. p. 195-210.

17. Smith FG. Beekeeping in the Tropics of Africa. Bees for Development. UK; 1960.

18. Food and Agriculture Organization of the United Nations. Tropical and sub tropical apiculture. Italy: FAO Agricultural Services Bulletin 68; 1986. p. 1-296.

19. Smith FG. Races of honeybees in East Africa. Bee World. $1961 ; 42: 255-260$.

20. Ruttner F. African races of honeybees. Proceedings of $X X V^{\text {th }}$ International Beekeeping Congress. France; 1975. p. 325-344.

21. Ayalew K. The Honeybee (Apis mellifera) of Ethiopia: A Morphometric Study. Norway: Agricultural University of Norway; 1990. p. 1-101.

22. Holeta Bee Research Center. Beekeeping Training Manual (unpublished). Ethiopia; 1997.

23. Amssalu B, Nuru A, Sarah R, et al. Multivariate morphometric analysis and behaviour of Honeybees (Apis mellifera) in the Southern Regions of Ethiopia. Apidologie. 2002;35:71-81.

24. Adgaba N. Atlas of pollen grains of major honeybee flora of Ethiopia. Holetta bee research centre. Ethiopia. 2007.

25. Gall MP, Thomas H. Beekeeping and honey production in South Western part of Ethiopia. Ethopia. 2012.

26. Holeta Bee Research Center. Beekeeping training manual. Ethiopia. 2004.

27. Mammo G. Ethiopia: a potential beekeeping giant. American Bee Journal. 1973;113(1):89-88.

28. Hackett KJ. Bee benefits to agriculture. Agricultural Research Magazine. USA; 2004.

29. Segeren P. Beekeeping in the Tropics. 5th ed. Agromisa, Netherlands; 1995:1-90. 
30. Nicola B. Taking the sting out of beekeeping. Arid Lands Information Network-East Africa (CD-Rom). Nairobi, Kenya; 2002.

31. International Bee Research Association. The management of African honeybees including the design of low cost hives. UK; 1997:4-14.

32. Crane E. The Hive and the Honey Bee. USA: Dadant \& Sons; 1976. p. $1-740$.

33. Vivian J. Keeping Bees. USA: Williamson Publishing; 1985. p. 1-240.

34. Haftu K, Daniel D, Gebru B, et al. Analysis of honey bee production opportunities and challenges in central zone Tigray, Northern Ethiopia. International Journal of Scientific and Research Publications. 2015;5(4):1-9.

35. Solomon B. Native beekeeping in the highlands of Bale, southeast Ethiopia. Proceedings of the 6th Ethiopian Beekeepers Association (EBA). Ethiopia; 2007:16-17.

36. Ethiopian Agricultural Research Organization. Apiculture research strategy. Animal Science Research Directorate, Ethiopia; 2000:30-42.

37. Admasu A, Nuru A. Effect of honeybee pollination on seed yield and oil content of Niger (Guizotiaabyssinica). Proceedings of the first National Conference of Ethiopian Beekeepers Association. Ethiopia; 2002. p. $67-73$.

38. Adimasu A, Gizaw E, Amsalu B, et al. Effect of Honeybee pollination on seed Allium cepa: Holetta Bee Research Center, Ethiopia. Eth J Anim Prod. 2008;8(1):79-84.

39. Bureau of Agriculture, Amhara National Regional State. Strategic plan document. Ethiopia; 2003:75-77.

40. Desalegn B. Honeybee pest and predators of Ethiopia: Proceedings of the third National Annual Conference of Ethiopian Beekeepers Association (EBA). Ethiopia; 2001:59-67.

41. Teklu G, Dinku N. Honey bee production system, opportunities and challenges in selected districts of gedeo zone, southern nation, nationalities and peoples regional state, Ethiopia. International Journal of Research-Granthaalayah. 2005;4(4):49-63.

42. Crane E. A book of honey. USA: Scribners; 1980. p. 1-193.

43. Ayalew K, Gezahegn T. Suitability Classification in Agricultural Development. Ministry of Agriculture, Ethiopia; 1991.

44. Beyene T, David P. Ensuring small scale producers in Ethiopia to achieve sustainable and fair access to honey markets. Paper prepared for international development enterprises (IDE) and Ethiopian Society for Appropriate Technology (ESAT), Ethiopia; 2007.

45. Addis G, Malede B. Chemical Analysis of Honey and Major Honey Production Challenges in and Around Gondar, Ethiopia. Acad J Nutr 2014;3(1):6-14
46. Amir P, Knipscheer HC. Conducting On-Farm Animal Research: Procedures and Economic Analysis. Winrock International Institute for Agricultural Development, USA; 1989. p. 1-253.

47. Ayalew K. Report on honey and beeswax production of Ethiopia: Proceeding of the fourth National Annual Conference of Ethiopian Beekeepers Association (EBA). Ethiopia; 2003:3-5.

48. Brad Bear B. Taking the sting out of beekeeping rid lands of information network east Africa (CD-Rom). Ethiopia; 2002:1-4.

49. Bureau of Agriculture, Amhara National Regional State. Special report on technology packages. Ethiopia; 2003:4-6.

50. Creswell JW. Educational research: planning, conduction and evaluating quantitative and qualitative research. USA: Pearsons; 2012. p. 1-672.

51. Central Statistical Authority. Agricultural sample survey 2012/13 [2005 E.C.]: Report on Livestock and Livestock Characteristics (Private Peasant Holdings). Ethiopia: Federal Democratic Republic of Ethiopia Central Statistical Agency; 2013. p. 1-188.

52. Central Statistical Agency. Agricultural sample survey of 2007: Volume II Report on Livestock and Livestock Characteristics (Private Peasant Holdings). Federal Democratic Republic of Ethiopia Central Statistical Agency, Ethiopia; 2007. p. 1-128.

53. Gebreagziabher A, Mohammed T, Gangwar SK, et al. Performance of Apis Mellifera spp. on Honey and Beeswax Production. In Different Type Of Beehives In Enda Mekoni Woreda, Tigray Region, Ethiopia; 2014.

54. Gezahegn T. Moisture content of Ethiopian honey. Ethiopian Beekeepers Association Newsletter. 2002;3(1):1.

55. Gizachew G, Sefinew A, Amssalu B, et al. Prevalence and associated risk factors of Bee Lice in Holeta and its surroundings, Ethiopia. $J$ Veterinar Sci Technol. 2013;4:130.

56. Jones R. Beekeeping as a business. Commonwealth Secretariat. UK 1999:1-70

57. MOA. Comprehensive bees and beeswax marketing. 2nd draft. Addis Ababa, Ethiopia: MOA; 2003.

58. Nuru A. Quality state and grading of Ethiopian honey. Proceedings of the first National Conference of Ethiopian Beekeepers Association (EBA), Ethiopia; 1999:74-82.

59. Tilahun G. Towards Realization of Amhara Region's Full Beekeeping Potential: The case of Bahir Dar Zuria and Dangla District, Ethiopia. Netherlands: Larenstein University; 2006. 